\title{
THE IMPLEMENTATION OF COOPERATIVE INTEGRATED READING AND COMPOSITION (CIRC) TO PROMOTE READING COMPREHENSION IN ELEMENTARY SCHOOL
}

\author{
Fidrayani, Maya Julia \\ UIN Syarif Hidayatullah Jakarta \\ Email : fidrayani7276@uinjkt.ac.id,majul.julia@gmail.com \\ Naskah diterima : 14 April 2017, direvisi : 20 April 2017, disetujui : 1 Mei 2017
}

\begin{abstract}
Many aspects of life need reading activities. Reading to understand the meaning of words called reading comprehension. This study is using descriptive analysis to determine how the implementation of the Cooperative Integrated Reading and Composition (CIRC) to promote reading comprehension. The aspects in reading comprehension are: a) the ability to grasp the meaning of words and phrases used by the author, b) the ability to grasp the meaning of explicit and implicit meaning, c) the ability to make inferences. Steps in the CIRC are: a) forming a group with four to five students are heterogeneous, b) the teacher gives an explaining in accompliance with the learning topics, c) students work together, reading and find the main idea and give a response to the discourse and written on a sheet of paper, d) presented the results of the group, e) the teacher makes a conclusion with his students, f) ending the class. Implementation CIRC in reading comprehension are already visible in measures of activities so that learning objectives can be achieved and reading comprehension can also be developed. Implementation CIRC in reading comprehension can be used by further research using distinct methodologies.
\end{abstract}

Keywords : CIRC, reading comprehension, elementary school

Pengutipan: Fidrayani., Julia, Maya. (2017). The Implementation of Cooperative Integrated Reading and Composition (CIRC) to Promote Reading Comprehension in Elementary School. JMIE: Journal of Madrasah Ibtidaiyah Education, 1(1), 2017, 111-121. sd.v1i1.28.

\section{INTRODUCTION}

Reading is the one of language competence that should be mastered by the student especially speaking, writing, and listening. In life, practically need reading. This is a key highlight in the world of education to create competent human resources in a particular language reading skills. 
The ability to read is needed by all learners. As has been said before, almost every aspect of life involves reading activities including teaching and learning activities. The information and knowledge in the books can be obtained through reading. Although the knowledge and the information can be obtained from the learning activities other than reading, but the reading still has an important role in acquiring information and knowledge of students.

Isah Cahyani and Hodijah (tth) suggested the main purpose of reading is to seek and obtain information, including the content, understand the meaning of the passage. It means comprehending the meaning of text is very important ability in reading. Reading is play an important role in building students' knowledge. Readers in this case students can explore and get a variety of information and knowledge contained in books or other writing media through reading comprehension. In other words, reading comprehension can be likened to a gate opener knowledge, because by being able to understand the contents of the reading, the reader can capture much more information, and not only is said in the text, but also the meanings implied other than the content of reading that he was reading.

Some of these factors in line with the results of research been done before at students in Indonesia. Research shows that students' interest in Indonesia is still relatively low. This is evidenced by the results of studies that Indonesia was ranked last out of 27 countries studied (Iskandarwassid \& Dadang Sunendar, 2013: 245). Nurida MR, et. al (2) states that in Indonesia the reading has not become a trend, and according to statistics there are Indonesia's population is illiterate. This phenomenon can be seen in the data published by UNESCO states that 497 Indonesian population is illiterate. While the reading trend in Indonesia, according to statistics published by BPS (Central Bureau of Statistics) 2003-2012 year was defeated by the trend of watching television. So, Indonesian people in each year rather watch television than read.

The other research proved weak reading comprehension among children in Indonesia. In 2009, Indonesia had participated in the Progress in International Reading Literacy Study (PIRLS) is an international study in the field of reading in children throughout the world aimed to obtain information about the ability of Indonesian students in the field of literacy in reading than students in other countries. The results of the study showed that the average Indonesian children are at fourth from bottom of the 45 countries in the world (Aryani, Samadhy, Sismulyasih, 2012: 2)

Teaching and develop reading comprehension in elementary school not be a simple task. The environment including teacher preparation and delivery of learning how to be one of the factors that influence the success of the students in the understanding of a reading. Therefore, every teacher must be able to present the study in accordance with the required skills of students in reading comprehension.

In fact, the implementation of learning in reading comprehension not using the model compliance with what is needed. Learning reading comprehension has been done by the teachers still use the lecture method followed by the reading, assignments where students answer questions about the text. The learning makes students less active and less enthusiastic about taking lessons. These conditions lead to the learning process has not lasted up so that the students' ability to understand the content of reading also less. To anticipate the learning problems, there should be a change in teaching reading com- 
prehension. Educators can use various methods attractive in the success of the students understand the content of a reading. One method that can be used is a method CIRC (Cooperative Integrated Reading and Composition).

Agustina (2015: 5-6) expressed his opinion that the method of the CIRC has been selected as one of the good teaching method with a variety of reasons,1) CIRC involves the ability of developing oral language, reading and writing as a whole in various phases are ordered; (2) CIRC developing critical thinking skills and develop social skills of students; (3) develop a sense of appreciation and confidence; (4) help students to appreciate themselves and proficient in the national language; (5) providing a learning environment that enables the learning of different materials or the materials studied over a wide range. In addition, the CIRC method basically aims to develop the participants' ability to understand the content of reading at the same time fostering the ability to write reproduction on the reading material they read. Based on the descriptions above, the CIRC relevant method for membelajarkan and improve students' reading comprehension.

Based on the background of the problems, there are some problems that can be identified as follows: a) the student's ability to understand the content of reading is still lacking, b) lack of understanding of students in interpreting punctuation in reading, c) the use of teaching methods that have not been according to the needs, d) the students' interest marked by the trend of watching television. The analysis of this study aimed to determine the implementation CIRC on the ability to read.

\section{LITERATURE REVIEW}

\section{The Nature of Reading}

Iskandarwassid \& Dadang Sunendar (2012: 246) describe reading is an event to get the meaning of what is written in the text. For this purpose, besides the need to master the language used, the reader should also enable a variety of mental processes in the system of cognition. In line with the statement, Crawley and Mountain in Rahim (2009: 2) also suggests that reading is essentially a complex involving a lot of things, not just recite the text, but also the activity involves visual, think, psycholinguistics, and metacognitive.

Reading is also defined by Cahyani, et al, (: 246) as a written language receptive skills. Reading skills can be developed in isolation, apart from listening and speaking skills. More broadly, Nurhadi in Laily (tth) said reading is a complex and complicated process. Complex means in the reading process involved a variety of internal factors and external factors reader. Internal factors such as intelligence, interest, attitude, aptitude, motivation, purpose of reading, and so forth. External factors can be in the form of reading facilities, social and economic background, and the tradition of reading. Complicated means of external and internal factors are interconnected to form a complex coordination to support reading comprehension. Based on the opinion of experts that has been stated above, it can be concluded that reading is a language skill that involves a variety of factors in order to obtain the information either express or implied contained in the readings. By reading, one can expand his knowledge as to dig a lot of messages or information of what he reads. 
Reading is an activity that has a purpose. When one reads, of course, there is the underlying purpose of these activities, so that reading becomes more meaningful. In general, the purpose of reading surrounded by Budinuryanta, Kasuriyanta and Imam Koermen (2008: 11.2) suggests four language objectives are : a) the purpose of reasoning, regarding the ability to think and disclosure of cultural values and social attitudes, b) the purposeTop of Form

of instrumental, concerning the use of language is learned that for the purposes of material and concrete. For example, in order to know use the tools, repair damage to the machine, studying the sciences and correspondence commercial, c) the purpose of integrative, concerning the desire for someone belonging to a community that uses the language (or dialect) as a language of daily life by mastering language, d) the purpose of culture, there are the people who are scientifically want to know or deepen his knowledge of a culture or society.

The main purpose of reading is to seek and obtain information, including the content, understand the meaning of the passage. Meaning, sense (meaning) is closely related to the intent, purpose or our intensive reading. Here are some important things related to the purpose of reading according to Isah, et. al (2016), : a) reading to find or know the discoveries made by the hero. Reading is called reading to obtain detailsdetails or facts (reading for details or facts), b) reading for main ideas (reading around for ideas), c) reading to determine the sequence or the organizational structure of the story (reading for sequence or organization), c) reading to conclude, read inference (reading for inference), d) reading for grouping, read to classify (reading to classify), e) reading rate, read evaluating (reading to evaluate), f) read to compare or contrast the (reading to compare or contrast).

Moreover, reading also has many other purposes. Ridwanuddin (2015: 165-166) suggests eight reading goal. As these goals are: (1) read relieve anxiety and anxiety; (2) when it is busy reading, someone shut out in ignorance; (3) the habit of reading makes people too busy to get in touch with people lazy and do not want to work; (4) by frequent reading, a person can develop flexibility and fluency in speaking the word; (5) read help develop ideas and clear thinking; (6) reading increases one's knowledge and improve memory and comprehension; (7) by frequent reading, one can benefit from the experience of others, such as copying wisdom of the wise, and the intelligence of scholars; (8) by frequent reading, one can develop the ability both to receive and respond to the science and to learn discipline and application in life.

It can be concluded that reading is not only aimed at obtaining information or understand the content of reading. By reading, one can expand their knowledge because of the involvement of cognitive activity when reading. In addition, reading can also develop other language skills such as speaking and writing. Reading activities are divided into two types of activities that silent reading activities and reading aloud. Silent reading is reading which rely solely on visual ability, comprehension, and retention in the face of reading, without a sound or moving his lips. While reading aloud is reading activities conducted by pronouncing every word, group of words, sentences from the text facing (Isah, et al,: 106). Top of Form

Tarin (2015: 14) also classifies the type of reading is based on the objectives to be 
achieved. By achieve the objectives contained in mechanical skills, the most appropriate activity of reading aloud, reading aloud. As for comprehension skills, namely reading activities appropriate reading silently. There are two types of reading aloud and reading silently. Reading silently subdivided into two groups: extensive reading (including reading the survey, skimming, and reading shallow) and intensive reading (including reading review of the content that is read carefully, reading comprehension, critical reading, reading ideas, and read the study of language in the form of reading and reading literary language).

\section{Reading Comprehension}

Reading comprehension is a reading and understanding of the content is limited to questions of what, how, why, where, and conclusions based on the problem of the content of reading (Laily,: 2). Santosa in Laily (: 4) explains that reading comprehension is a continuation of reading silently, began to be given in class 3 , read silently in order to understand the content of reading.

Various other sense related to reading comprehension also largely defined by experts. Somadayo (in Fuzidri, Thahar \& Abdurrahman, 2014: 2) explains that reading comprehension is reading activities that seek to understand the content of reading or text thoroughly. Someone said reading comprehension as well if it has the following capabilities. There are a) ability to understand the meaning of words and phrases used by the author, b) ability to grasp the meaning include of explicit and implicit meaning, c ) ability to produce inferences.

Soedarso in Fuzidri, et al (2014) also argues that reading comprehension is the ability to read to understand the main ideas and important details of the overall content of reading text. Moreover, Nasir interpretation Fajri in reading comprehension as a reader reading activities undertaken in order to create an understanding of the content contained in the reading (Nasir, tth: 2).

Based on the above, it can be concluded that reading comprehension is part of the silent reading activities aimed to examine the content of reading. The study referred to the content of reading text to understand from discovery main idea, comprehend the meaning either express or implied up to deduce the content of reading. Success in reading comprehension is influenced by many factors. The ability of the students to mastered a different reading. It depends on the vocabulary owned, interest, reach the eyes, the speed of interpretation, the background of previous experience, intellectual ability, familiarity with the idea of being read, the purpose of reading, and the flexibility to set the pace (Soedarso, 2005: 58-59).

Factors affecting the efficiency of reading presented by Ahuja \& Ahuja (2010: 7071) include two things, internal and environmental factors. Internal factors are factors that originate from within the reader. Internal factors include, the ability to hear sounds, speech defects, the habit of reading, and the purpose of reading. Environmental factors are factors that come from outside reader. These factors include lighting or lighting, the legibility of reading material, and the reader environment.

Pearson and Johnson in Zuchdi (2000: 23-24) also states the factors that are in the reader includes linguistic abilities, interest (how much concern the reader to the reading of faces), motivation (how much the reader cares about the reading assignment or general 
feelings about reading and school) and a collection of reading skills (how well the reader can read). External factors of the readers are divided into two categories of elements of reading and reading environment. Elements on the reading or textual features include text (difficulty reading) and the organization of the text (the kind of help available in the form of chapters and subchapters, composition writing, etc.). The environmental quality include factors: teacher preparation before, during, or general atmosphere of task completion (barriers, encouragement, etc.). All these factors are not mutually exclusive, but interconnected. Based on the description that has been described, it can be concluded that a person's reading comprehension is influenced by internal factors and external factors. Internal factors include the intellectual and linguistic ability, interest, motivation, and reading habits. External factors include environmental and linguistic text.

\section{Reading Comprehension Test}

The ability to read can be measured in various ways. A certain way might be to measure specific aspects of reading. There is no one best way to measure the ability to read, because each method has advantages and disadvantages. Farr \& Carey (in Arifin, 2010: 7) outlines some of the ways commonly used to measure reading comprehension. It is include: (1) multiple choice test, (2) test cloze, (3) read aloud, and (4) retrieval.

The purpose of the test is to determine the reading test and measure the level of ability to comprehend reading material. Djiwandono (Arifin, 2010: 8-9) describes that the level of reading ability is reflected in the level of understanding of the content of reading, both of which are clearly expressed in it (express), and only revealed subtly and indirectly (implicitly), or even just an implication of the content of reading. All of this is part and manifestation of the ability to understand the reading. Implementation of the reading comprehension test always starts with a text reading as a source for answers to the points test. The content, writing style, vocabulary and reading text that is necessary to ensure compliance with the field, writing style and understanding the range of test participants (Djiwandono, 2008: 118). Emphasis test reading is the ability to understand the information contained in the discourse. The levels of the revised Bloom Anderson (Yaumi, 2013: 92) that knowing (knowing), understanding (understanding), applying (applying), analysis (analyzing), evaluating (evaluating), and creates (creating). The ability of reading comprehension question in this research is the ability to understand the text as a whole. The ability of the invention is shown from the main idea, understand the meaning either express or implied up to deduce the content of reading.

\section{Cooperative Integrated Reading and Composition (CIRC)}

\section{The Nature of Cooperative Integrated Reading and Composition (CIRC)}

CIRC is defined as a cooperative model that introduces the latest techniques of practical training curriculum on teaching reading. CIRC is a comprehensive program for teaching and reading the art of writing (Darmayanti, 2014:5).

Slavin (Mustyka, 2016:5) describes that CIRC is a comprehensive program in the teaching of reading and writing to high-grade primary school. CIRC learning model is a special learning model Indonesian subject in order to read and find the main idea, subject 
matter, or the theme of discourse.

Based on the expert suggests, it can be concluded that the CIRC is learning that combines the teaching of reading and writing based on cooperation. This model is done in groups, thereby reducing the dominance of the teacher in the classroom. CIRC has three principle elements: activities related story, direct instruction in reading comprehension and integrated language arts/writing. This model carry out learning based on cooperation aimed at developing reading and writing skills in an integrated manner. Furthermore, Slavin (2005: 205-209) also mentions the main elements in the CIRC are: (1) a group reading; (2) teams; (3) The activities related to the story; (4) The examination by the couple; (5) test; (6) direct instruction in reading comprehension; (7) the art of speaking and writing integrated. Some explanation of the main elements of the CIRC which is as follows: a) group of readers, the students were divided into introduce new vocabulary, reviewing the old vocabulary, discussed the story after students read and so forth. In general, the discussion on this story should be structured to emphasize certain abilities such as creating and supporting predictions of the story and understand the components of the structure of the story, such as problem groove and troubleshooting information contained in the story. The CIRC learning model that can work well, it needs several components that support. Among these components are described by Slavin (2005: 3) as follows: a) team, in a learning activity this requires the formation of small groups beforehand consisting of between 4 to 5 people, b) the classification must be based on abilities possessed by the learners. It can be known by educators with regard to the value of the learners in the learning activities in advance, c) creativity, try educators were able to provoke creativity possessed by the learners. This can be done by assigning the tasks to the learners. d) group study, there are times in the learning activities are groups that need the help of the teachers. Because of this, then here the role of educators is more sensitive to the groups that need attention and assistance when experiencing difficulty in carrying out assigned tasks, e) to reward learning groups have a good group work. Thus, it will provoke a reaction from the other groups to try to get a similar award so that there will be a new motivation in learning activities. In line with the above statement, Slavin in Halimah (2014) mention that learning CIRC has several components. The components in question are: a) Teams, namely the formation of a heterogeneous group consisting of 4 or 5 students; b) Placement test, for example, obtained from the average value of daily tests before or based report cards for teachers to know the strengths and weaknesses of students in a particular field; c) Student creative, carry out the task in a group to create a situation where individual success is determined or influenced by the success of the group; d) Team study, namely stages of learning actions carried out by the group and provide assistance to a group of teachers who need it; e) Team scorer and team recognition, namely scoring against the group's work and give the award criteria against which succeeded brilliantly groups and groups that are considered less successful in completing a task; f) Teaching group, which gives the material briefly on the teacher ahead of group work; g) Facts test, which is the implementation of a test or quiz based on facts obtained by the students; h) Whole-class units, namely the provision of a summary of the material by the teacher at the end of time learning with problem solving strategies.

The CIRC model was composed of various elements or components. As for the main element in the method of the CIRC is a reading group, team, event-related activities, examination by the couple, test, direct instruction in reading comprehension, as well as the art of speaking and writing integrated. 
CIRC according to Halimah (2014) basically aims to improve participants' ability to understand the content of the reading at the same time fostering the ability to write reproduction on the reading material they read. CIRC help students learn reading comprehension abilities that can be applied in a straight forward. CIRC method can help teachers integrate reading and writing in the implementation of learning to read. In line with the statement, Slavin (2005: 203) says that the main purpose of the CIRC is using a co-operative teams to help students learn reading comprehension abilities that can be applied broadly.

As noted previously, CIRC is a learning model that combines reading and writing. The main objective of the CIRC method of improving reading comprehension at the same time fostering the ability to write.

CIRC is the available model in cooperative learning. Riyanto defined (2009: 267) is designed to teaching academic skills as well as social skills (social skills), including interpersonal skills. CIRC has a sequence of steps used in the learning process. These steps are used to implement a lesson plan about to be implemented for the purpose of learning can be achieved with maximally. Steps in CIRC expressed by Suprijono (2016: 149-150) as follows: a) forming a group whose members 4 are heterogeneous, b) the teacher gives a discourse / clipping in accordance with the learning topics, c) students reading to each other to work together and find the main idea and give a response to the discourse / clippings and written on sheets of paper, d) presented / read out the results of the group, e) the teacher makes a conclusion together, $\mathrm{f}$ ) the ending.

Slavin in Sukiastini, Sadia \& Suastra (2013: 3) explains that the cooperative learning model CIRC also be implemented using several phases as follows: a) The first phase of onboarding. In this phase, the teacher did apersepsi and students' initial knowledge about the materials to be provided, b) the second phase, the organization. The teacher divides the students into several groups, with academic heterogeneity. c) The third phase is the introduction of the concept. By way of introducing a new concept that refers to the findings during exploration, d) The fourth phase, namely the phase of publication. Students communicate the results of its findings, prove, demonstrated about the material covered either within the group or class. e) The fifth phase, namely the phase of strengthening and reflection. In this phase, the teacher provides reinforcement associated with the material learned through explanations or provide concrete examples in everyday life. Furthermore, the students were given the opportunity to reflect on and evaluate their learning results. The application of the method starts from the CIRC in learning groups. Then proceed with reading and exploration activities, presenting or communicating the results of focus group discussions, and ends with the strengthening and reflection. The advantages of learning the CIRC according to Slavin (in Halimah, 2014: 8) is: a) the model of cooperative learning CIRC very appropriate to increase the students' understanding of the learning material, b) predominance of teachers in learning is reduced, c) Students are motivated on the results carefully for work in the group, d) the students can understand the meaning of questions and check their work e) to help students who are weak in understanding assigned tasks, f) to enhance learning outcomes, especially in solving the teacher problems, g) students are able to respond freely, trained to be able to cooperate and respect the opinions of others. As for the shortage of CIRC method is at the time of presentation, only students who are active, who performed requires a relatively long time, the activi- 
ties of the group could not run as expected. However, the use of CIRC cause a problem is if the teacher was teaching one group read, other students in the class should be given activities they can accomplish with a little guidance from the teacher. This can be avoided if the teacher can manage time and the class as well. The CIRC is a method that combines the teaching of reading and writing based on cooperation. The implementation of this method starts with group activities, giving discourses, reading and writing, present / communicate the results of the discussion, conclusions, and covered with reinforcement and reflection.

\section{METHODOLOGY}

The qualitative approach was used by researcher to describe the phenomenon of the weakness of teachers in implementing the learning model that could develop the skills of elementary school students' reading comprehension.

\section{CONCLUSION AND DISCUSSION}

Poorly students in understanding the content of a reading into its own obstacles as well as for students to obtain information and knowledge contained in a variety of learning resources in the form of writing. Indonesian language learning that is held still dominated by the use of the conventional method of lectures, assignments, and frequently asked questions. It is seen less varied and monotonous so that the possibility of making students become bored and less active and less enthusiastic in following the learning process.

Underlined the importance of reading comprehension that must be mastered by the students, then the teachers as educators become facilitators are vital for the continuity of the learning process of reading comprehension. Educators must present a lesson in accordance with what is required of the student. When learning methods are used in accordance with the needs.

\section{REFERENCES}

Agustina, R. 2015. Penerapan Metode Cooperative Integrated Reading And Composition (Circ) Untuk Meningkatkan Kemampuan Mengapresiasi Cerita Rakyat Pada Siswa Kelas VIIC SMP Negeri 16 Pontianak. Jurnal Ilmiah Progressif. Vol.12 (35).

Ahuja, Pramila dan G. C. Ahuja. 2010. Membaca Secara Efektif dan Efisien. Bandung: P'T Kiblat Buku Utama..

Anwar, D. 2003. Kamus Lengkap Bahasa Indonesia. Surabaya: Amelia Surabaya.

Arifin, Muhammad Zainal. 2010. Pengaruh Penguasaan Kosakata, Sintaksis, dan Minat Baca terhadap Kemampuan Memahami Bacaan Teks Berbahasa Inggris. Jurnal Studi Agama dan Masyarakat. Vol. 4 (1).

Aryani, Suprobo, Umar Samadhy, dan Nugraheti Sismulyasih. 2012. Peningkatan Keterampilan Membaca Pemahaman Melalui Strategi Know-Want-Learned (KWL) Pada Siswa Kelas IVA SDN Sekaran 01 Semarang. Joyful Learning Journal. Volume 1 (1).

Budinuryanta, Kasuriyanta, dan Imam Koermen. 2008 Pengajaran Keterampilan Berbahasa. Jakarta: Universitas Terbuka. 
Cahyani, Isah dan Hodijah. 2007. Kemampuan Berbahasa Indonesia di SD. Bandung: UPI PRESS. 2007.

Darmayanti. 2014. The Implementation Of Cooperative Integrated Reading And Composition (Circ) Method In Teaching Narrative Text To Improve Students' Reading Comprehension At The Eleventh Grade Students Of Man 2 Model Makassar. Ethical Lingua Journal. Vol. 1 (2).

Djamarah, Syaiful Bahri. 2002. Strategi Belajar Mengajar. Jakarta: PT Rineka Cipta.

Djiwandono, M. Soenardi. 2008. Tes Bahasa: Pegangan Bagi Pengajar Bahasa. Jakarta: PT Indeks.

Fuzidri, Harris Effendi Thahar, Abdurahman. 2014. Peningkatan Keterampilan Membaca Pemahaman Melalui Model Pembelajaran Kooperatif Tipe CIRC Siswa Kelas VIII 5 MTSN Kamang Kabupaten Agam. Jurnal Bahasa, Sastra, dan Pembelajaran. Volume 2 (3).

Halimah, A. 2014. Metode Cooperative Integrated Reading And Composition (Circ) Dalam Pembelajaran Membaca dan Menulis Di SD/MI. Jurnal Auladuna. Vol. 1 (30).

Iskandarwassid dan Dadang Sunendar. 2013. Strategi Pembelajaran Bahasa. Bandung: PT Remaja Rosdakarya.

Kunandar. 2010. Langkeah Mudah Penelitian Tindakan Kelas Sebagai Pengembangan Profesi Guru. Jakarta: PT Raja Grafindo Persada.

Laily, IF. 2014. Hubungan Kemampuan Membaca Pemahaman dengan Kemampuan Memahami Soal Cerita Matematika Sekolah Dasar. Jurnal EduMa. Volume 3 (1).

Mustyka. 2016. Peningkatan Keterampilan Menulis Esai Melalui Model Cooperative Integrated Reading And Composition (Circ). Jurnal Pendidikan Rokania. Vol. I (2).

Nasir, Ernawati. th. Upaya Meningkatkan Kemampuan Membaca Pemahaman Dengan Pendekatan Keterampilan Proses Pada Siswa Kelas V SDN Sabelak Kecamatan Bulagi Selatan. Jurnal Kreatif Tadulako Online. Volume 5 (9).

Nurhidayati, Fitria. 2014. Peningkatan Keterampilan Membaca Pemahaman Dengan Sustained Silent Reading Di Kelas IV Sekolah Dasar Negeri Mendak Ponjong Gunungkidul. Skripsi. Yogyakarta: Universitas Negeri Yogyakarta. 2014. Tidak dipublikasikan.

Rahim, F. 2009. Pengajaran Membaca di Sekolah Dasar. Jakarta: Bumi Aksara.

Rahma, Nurida Maulidia, dkk.tth. Strategi Peningkatan Minat Baca Anak. Jurnal Administrasi Publik (JAP). Vol. 3.

Rahman, Arif. 2012. Implementasi Penggunaan Mind Map dengan Model Pembelajaran Kooperatif Tipe CIRC (Cooperative Integrated Reading and Composition) Dalam Meningkatkan Kemampuan Pemahaman Matematika Pada Siswa SMP Negeri 3 Ceper Klaten. Skripsi. Yogyakarta: UIN Sunan Kalijaga.. Tidak dipublikasikan.

Ridwanuddin, D. 2015. Bahasa Indonesia. Jakarta: UIN Press. 2015.

Riyanto, Y. 2009. Paradigma Baru Pembelajaran: Sebagai Referensi bagi Guru/Pendidik dalam Implementasi Pembelajaran yang Efektif dan Berkualitas. Jakarta: Kencana.

Sanjaya, Wina. 2006. Strategi Pembelajaran: Berorientasi Standar Proses Pendidikan. Jakarta: Kencana.

Sanjaya, W. 2008. Perencanaan dan Desain Sistem Pembelajaran. Jakarta: Kencana. 2008. 
Slavin, Robert E. 2005 Cooperative Learning:Teori, Riset dan Praktik. Bandung: Nusa Media.

Soedarso. 2005. Speed Reading: Sistem Membaca Cepat dan Efektif. Jakarta: Gramedia Pustaka Utama.

Sudijono, Anas. 2012. Pengantar Statistik Pendidikan. Jakarta: Rajawali Pers.

Sugiyono. 2006. Metode Penelitian Kuantitatif, Kualitatif dan R\&D. Bandung: Alfabeta. 2006.

Sukiastini, I. G. A. N. K., I. W. Sadia dan I. W. Suastra. 2013. Pengaruh Model Pembelajaran Cooperative Integrated Reading And Composition Terhadap Kemampuan Pemecahan Masalah Dan Berpikir Kreatif. e-Journal Program Pascasarjana Universitas Pendidikan Ganesha. Vol. 3.

Sukmadinata, N. S. 2013. Metode Penelitian Pendidikan. Bandung: PT Remaja Rosdakarya.

Suprijono, Agus. 2016. Cooperative Learning: Teori dan Aplikasi PAIKEM. Yogyakarta: Pustaka Belajar.

Tarigan, Henry Guntur. 2015. Membaca. Bandung: Angkasa. 2015.

Taufiq. 2013. Peningkatan Kemampuan Membaca Ekstensif Teks Berita Melalui Metode Cooperative Integrated Reading and Composition (CIRC) Siswa Kelas VIII-A MTS Darussalam Kanten Trucuk Bojonegoro Tahun Pembelajaran 2012/2013. Jurnal Ilmiah.

Yaumi, M. 2013. Prinsip-Prinsip Desain Pembelajaran. Jakarta: Kencana.

Zuchdi, D. 2000. Strategi Meningkatkan Kemampuan Membaca: Peningkatan Komprehensi. Yogyakarta: UNY Press. 2000. 